\title{
Analysis Of Constructive Learning Models In Forming Religious Characters Of Early Childhood
}

\author{
Mulyati $^{1}$, Tjipto Sumadi ${ }^{2}$, Elindra Yetti ${ }^{3}$ \\ 1Mahasiswa S3 PAUD UNJ .Jakarta,Indonesia \\ ${ }^{2,3}$ UNJ,Jakarta,Indonesia \\ ${ }^{1}$ mulyatinizam71@gmail.com, ${ }^{2}$ tjiptosu@yahoo.com, ${ }^{3}$ elindrayetti@unj.ac.id
}

\begin{abstract}
The purpose of this study is to provide an overview of the development of learning models that can stimulate students to interpret every learning activity in shaping the character of early childhood. The research method is a qualitative method in which the researcher captures the phenomenon of the development of religious and moral values of early childhood is only limited to habituation and the discovery of data that the teacher does not compile a special program of character development in learning. The study was conducted in Jakarta with 60 samples consisting of University students Open early childhood education programs majors who are early childhood education programs teachers in DKI Jakarta. Data analysis techniques from interviews, observation and questionnaire distribution and also documentation. The results of the study stated that a constructive learning model is needed that is able to give meaning to the learning process in character development
\end{abstract}

Keywords

constructive learning models and character of early childhood

Article Received: 10 August 2020, Revised: 25 October 2020, Accepted: 18 November 2020

\section{Introduction}

Early childhood education in various studies, both theory and application that is always developing, illustrates the importance of systematically arranged and meaningful learning designed in play activities. Until today the implementation of early childhood education has always been developed, both in terms of learning models and learning strategies and even learning media. The development of early childhood learning models constantly undergo changes which are followed by changes in the development of early childhood competencies. Early childhood competencies displayed in the form of knowledge, skills and attitudes are the result of the learning development process that has been applied and the aspects of development always refer to aspects of religious and moral values, cognitive, language, social emotional, motor and arts. This competency is assessed according to the results of the studies that have been empirically proven.

In the learning process carried out by early childhood education programs teachers character development is interpreted as a process of inculcation of cultivation which is carried out at the beginning, core and closing of learning activities. However, it is generally found that there are no programs developed specifically included in the learning planning undertaken by the institution. Assumptions about character development are behaviors that are carried out only through routine habits (Setiawati, 2006)

The 2013 curriculum is a curriculum that began to be applied in Indonesia and entered into force since its enactment in 2014 through Pemrendikbud 137 and 146 in 2014. In its application the 2013 curriculum outlines all aspects of development with detailed indicators in each of its aspects namely cognitive, language, physical motor, social emotional and arts. However, aspects of the development of religious and moral values do not describe in detail the indicators that are expected to emerge at the end of the learning process. This is the concern of researchers to conduct a theoretical study of indicators of religious and moral values by focusing on the standard level of achievement of the development of religious and moral values aged 5-6 years. This study is expected to become a teacher's reference to describe it in detail in the Weekly study plan and daily lesson plan that will be applied in class.

In standard level of achievement of child development aged 5-6 years aspects of the development of religious and moral values referred to in this study are Islamic religion, including: 1) Knowing God as the creator of Him 2) Performing religious worship activities, 3) Accustomed to doing personal and environmental cleanliness, 4) Behaving honestly, helper, polite, respectful and sportive 5) Foster a love for God

The five aspects that are fostered in the inculcation of religious and moral values are carried out through play activities and must also be structured in a good system so that they are formed through behavior and speech in accordance with religious teachings. The process of development in the classroom is determined by the achievements to be achieved by the teacher when doing the learning process. Therefore, as a teacher, especially early childhood education program, teachers must really understand the indicators to be achieved in detail in accordance with the stages of development and also the stages of learning so that the expectations of development achievements are in accordance with the development guidelines for children aged 5-6 years. The inculcation of religious and moral values will manifest into daily behavior called character. Character is a permanent attitude in the individual as a form of success in the learning process.

Thomas Lickona in his book 'Character Matters "(Thomas Lickona, 2016) quotes from Martin Luther King, Jr.'s speech that said" that he dreamed of the day when all Americans would be judged not by their skin color but by their 
character. " ? The content of good character is goodness. Goodness - such as honesty, courage, justice and compassion - is a disposition to behave morally. Character is good objectivity for human quality, whether human is known or not. These virtues are affirmed by people and religions throughout the world. Because it is intrinsically good, has a right to our conscience. Virtue transcends time and culture; justice and kindness. Goodness meets ethical criteria, namely: 1) Goodness determines what it means to be human. We become whole human beings when we do benevolence and are generous, unselfish, just not unfair, honest not cunning, 2) Virtue increases the happiness and well-being of an individual, 3They serve the public interest, enabling us to live and work in society, 4) They meet the classic ethical test of reversibility and universality.

In the same book Thomas Lickona also outlines 10 essence of virtue that will build a strong character, namely: 1) According to Ancient Greek wisdom (wisdom) as a teacher of virtue. Wisdom is a good judgment. It allows us to make reasonable and good decisions for us and also for others. Policy allows us to see what is right, to know what is truly important in life and to set priorities, 2) Justice (justice) means respecting the rights of all people. The principle of justice is to treat others as we want to be treated as a cultural and religious root throughout the world, 3) Courage (fortitude) According to James Stenson courage is an inner toughness that allows us to overcome or withstand difficulties, defeat, discomfort, and pain. The aspect of courage is courage, tenacity, patience, perseverance, endurance and self-confidence, 4) Self-control (temperance) is the ability to regulate ourselves. This allows us to control our emotions, manage desires sensual and lust, the pursuit of pleasure, even pleasure that is considered prevalent in the age of fashion rn. 10 Love (love). Love is the desire to sacrifice yourself for the benefit of others. Kinds of the kindness of love are empathy, compassion, generosity, service, loyalty, patriotism and forgiveness, 2) A positive attitude. Part of a positive attitude is hope, enthusiasm, flexibility, and a sense of humor. 3) Working hard. Working hard includes initiative, perseverance, goal setting and ingenuity, 4) Integrity. The meaning of integrity is to follow moral principles, to be loyal to moral awareness, to guard our words, and to stand on what we believe in. 5) Gratitude. The meaning of gratitude is something we must enjoy for what we get as a form of love, 6) Humility. According to David Issaacs humility is to acknowledge both of our inability and ability, and to suppress our ability to be in service without attracting attention and expecting applause.

\section{Constructive learning model}

Constructivist is the process of building or compiling new knowledge in students' cognitive structures based on experience. The constructivist philosophy was conceived by Mark Baldawin and was developed and deepened by Jean Piaget who considered that knowledge was formed not only from objects, but also from the ability of individuals as subjects to capture every object he observed. (Wina Sanjaya, 2015)

Constructive building knowledge from what he knows (AlHattami, 2019) by the teacher providing feedback on the learning process that he has done so that the achievement of learning objectives that have been set. Constructive feedback enhances students' ability to understand the learning material they have acquired so as to strengthen prior knowledge.

Children build moral understanding through the social interactions they experience. Constructivist teachers facilitate children in class so students can be directly involved in resolving conflicts or problems experienced by students in class, making decisions and social problems. Constructivist teachers build children's interests and goals in building children's reasoning, children's experiments and encouraging children to be able to work together among all class members. (Kusumawati, Intan, Zuchdi, 2019)

That knowledge comes from outside and is constructed by and from the individual itself which is gained from the experience he experiences (Alonso et al., 2009).

Constructivism refers to the cognitive approach theory where the cognitive psychology approach emphasizes the importance of internal human and mental processes. In the view of cognitive experts human behavior that seems unmeasurable and explained without involving mental processes, such as; motivation, intentions, beliefs and so on (Shah, 2014)

In constructive theory knowledge is developed in the memory of understanding, attention, comparison, planning and conclusions starting from the end of childhood, adolescence and approaching adulthood (WoonSuhc, 2017). Learning developed in constructivist theory is creative and meaningful learning. Creative and meaningful learning is learning that is closely related to constructivist Vygotsky thought (social and Emancipator Contructivism). This understanding holds that students construct knowledge or create meaning as a result of thinking and interacting in a social context. This learning theory is a theory of meaning creation. (Karim, 2017)

Tasker suggests 3 emphasis on constructivist theory. First the active role of students in meaningfully constructing knowledge. Second: the importance of making connections between ideas in meaningful construction. Third: linking ideas and new information received.

Wheatley mentions 2 main principles in learning according to constructivist theory, namely knowledge cannot be obtained passively, but actively by the cognitive structure of students. Second: cognition is adaptive and helps to organize through real experiences that children have

Ausubel believes that meaningful learning only happens when students discover knowledge for themselves. Hanburry stated a number of aspects in relation to learning, namely: 1) Students construct knowledge by integrating the ideas they have. 2) Learning becomes more meaningful because students understand. 3) Learner strategies are more valuable. 4) Students have the opportunity to discuss and exchange experiences and knowledge with their friends.

Tytler proposes some suggestions relating to the design of learners according to constructivist theory 1) gives students the opportunity to express their ideas in their own language 2) gives students the opportunity to think about their experiences so that they become creative and imaginative 3) gives students opportunities to try new ideas 4) provide experience related to the ideas that students have had 5) encourage students to think about changing their ideas 6) create a conducive learning environment. (Karim, 2017). 


\section{Early childhood character}

Character is the application of values that are understood, believed and applied in society. The application of values in the form of behavior is believed to be a belief in knowledge, experience, understanding and also the truth of that value. Character is the character, character, character, or personality of a person that is formed from the internalization of various virtues (virtues) that are believed and used as a basis for perspective, thinking, acting, and acting. According to Philips in (Early, 2019) character is a collection of values that lead to a system that underlies the thoughts, attitudes, and behaviors displayed, so the characters have the characteristics, among others, as follows: 1) who and what you are when people others are looking at you, 2) character is the result of values and beliefs, 3) character is a habit that becomes second nature, 4) character is not a reputation or what others think of you, 5) character is not how good it is others, 6) characters are not relative.

Freedom to learn to change behavior based on an understanding of the values that exist in society and make decisions on these values so that it becomes a solid foundation of character. Because the character will respond to the problems he faces in each of his life's journey so that it will always be strongly attached to him. The application of values that have been believed to be essential truth is a reference for action in resolution

problem. Therefore early understanding needs to be given to children so that children are able to respond to the conditions they face.

Character values taken are the development of the standard level of achievement of child development (STPPA) aged 56 years in aspects of religious and moral values. Lalompoh and Kartini Esther Lalompoh (2017) states that the relevant moral development of children is assessed according to the Pancadaya theory, namely

(a) hereditary strength, (b) environmental strength, (c) strength derived from hereditary and environmental collaboration; (d) has the power of initiative, and (e) the power of Almighty God. (Zulkifli N, 2019) This study is a development of learning about aspects of NAM in the 2013 curriculum as a basis for religious character of early childhood. The values embedded are Islamic values based on character values in the Qur'an, namely; know God as His creator, perform Islamic religious activities, accustomed to doing personal and environmental cleanliness, behave honestly, helpful, polite, respectful and sportive; and foster a love for God.

The dimension of knowing God as His creator includes a study of what God created for the survival of human beings including moving, growing and immovable beings. Creatures move like humans and animals by giving love, care and also food. Growing creatures are plants by giving life that does not damage the environment and natural atmosphere. Inanimate creatures such as the universe and celestial bodies by preserving the environment without destroying it (Nurjanah, 2018)

Dimensions of performing Islamic religious activities include mentioning prayer times and the number of rak'ahs, saying daily prayers at least 5 daily prayers, saying prayers with the correct greeting, being able to do prayer movements correctly and in sequence / tumaninah. (Didik, 2015)

Dimensions accustomed to doing personal and environmental hygiene include being able to maintain the cleanliness of their clothes, maintain the cleanliness of their environment and maintain a good eating attitude. (Syamsudin, 2017)

The dimensions of being honest, helpful, polite, respectful and sportive include honest ability at every opportunity, giving help to friends in need, being polite to everyone, respecting older people, showing sportsmanship at every opportunity of play and showing attitude to admit mistakes. One way to achieve character is to integrate the character of education in every learning. The values of the main characters that must be manifested in the attitudes and behavior of students as a result of the process of character education are honest (exercise), intelligent (thinking), tough (sports), and caring (taste and Carsa). ( $\square$ \&, Samsudi, 2019) The dimension of growing love for Allah is showing God's creation and human creation, showing patient attitude, being able to distinguish God's creation from human creation, being able to talk about his feelings both happy, sad with good expressions through attitude or words, expressing his judgment on people others positively. The five dimensions will be elaborated in the learning process. (Setiawati, 2006)

\section{Research methods}

The research method in this article is a qualitative research method. Observations are carried out by distributing questionnaires and interviews as much as 60 PAUD teachers who are in Jakarta. Data is taken for the 5-6 years age group (group B).

Analysis of the need for a learning model that is able to interpret the learning process found data in the following diagram:

\section{The results of the analysis of the learning model needs}

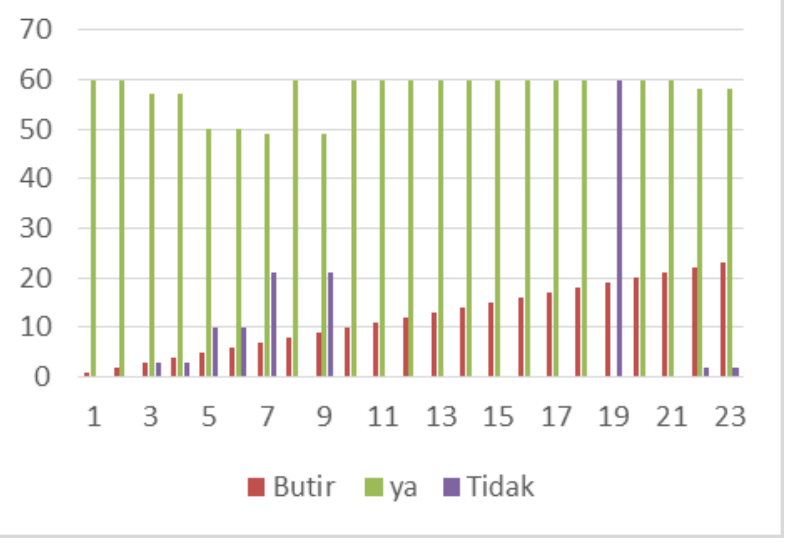

The results of the analysis of the questionnaire distributed to 60 kindergarten teachers in DKI Jakarta concluded that the need for a learning model specifically designed for developing indicators of religious and moral values reached $96.6 \%$ where learning activities were limited to the habit of reading daily prayers, prayer movements, pronunciation of 
thoyibah and asmaul husna sentences. Whereas giving punishment to children who behave badly found $100 \%$ of teachers did not do it

\section{Research result}

Development of learning models that are part of achieving learning objectives is one of the efforts of institutions to provide the best for the education community. Murniyati (Murniyati, 2017) that the implementation of religious character values in character education is as follows: 1). Teacher's thinking about the importance of religious values in character education is one of the sources that underlies character education and is very important to instill in students from an early age because with a strong religious provision, which is instilled early on will strengthen the moral foundation of students in the future, students will not be easy affected by bad things. 2). the role of schools in supporting the implementation of religious character values in character education, namely providing facilities that are used to support the implementation of programs held at school, giving permission to teachers who have ideas to organize a program of activities, supporting the existing activities outside of school, and provide a good example for students. 3). implementation of religious values in character education through self-development programs consisting of routine activities that exist in school, spontaneous activities undertaken by teachers to students, exemplary provided by teachers, and school conditioning created in such a way. Implementation through subjects by inserting them in subject matter or moral messages from the teacher and through school culture consisting of cultures that exist in class, school, and outside of school.

Moral education must be based on faith education. If aqidah education which is the foundation of moral education is neglected, then the consequences after the child is an adult he will grow on the basis of wickedness, deviation, error and disbelief. (Zainuddin Syarif, 2014). Moral education material consists of 3 namely moral towards God as the creator of the universe, moral towards humans as social beings and moral towards the universe as supporting life and also as human needs. All of these materials are translated with different concepts. because his subjects are different with different characteristics. His activities also vary according to the objectives of the moral education. Morals with God are carried out with worship with confidence. Morals with humans are carried out by interacting properly and politely while morals with the universe are carried out by preserving sustainability and take care of him.

Religious values contain meaning in life prepared for the next life (hereafter). Where the activities carried out in the world is a provision for the hereafter, which refers to the love of Allah SWT. Therefore the religious character is the character of the "hereafter" with its application to relations to God and relations to humans.

Religious character is a character inherent in early childhood by the way children interpret every habituation activity as a necessity.

\section{References}

[1] Al-hattami, A. A. (2019). Feedback. 12(1), 885-894.

[2] Alonso, F., Manrique, D., \& Viñes, J. M. (2009). Computers \& Education A moderate constructivist e-learning instructional model evaluated on computer specialists. Computers \& Education, 53(1), $57-65$.

https://doi.org/10.1016/j.compedu.2009.01 .002

[3] Didik, S. (2015). Perkembangan Nilai Agama Dan Moral Anak. Perkembangan Nilai Agama Dan Moral Anak Dan Pendidikan Keagamaan Orangtua, 3(Maret), 1-20.

[4] Dini, A. U. (2019). Peran Literasi Moral Meningkatkan Karakter Religius Anak Usia Dini Shanti Sudjarwati 1 , Eny Fariyatul Fahyuni 2. 10(2), 219-229.

[5] Karim, D. dan S. (2017). Pembelajaran Abad 21 (1st ed.). Gava Media.

[6] Kusumawati, Intan,Zuchdi, D. (2019). Pendidikan Moral Anak Usia Dini Melalui PENDEKATAN KONSTRUKTIVIS. Academy of Education Journal, 10, 64.

[7] Murniyati. (2017). Implementasi Pendidikan Karakter Religius Terhadap Anak Usia Dini. Prosiding Seminar Nasional 20 Program Pascasarjana Universitas Pgri Palembang 25 November 2017, November.

[8] Nurjanah Pascasarjana UIN Sunan Kalijaga Yogyakarta Jl Lakda Adi Sucipto, S., \& Yogyakarta, D. (2018). Perkembangan Nilai Agama Dan Moral (Sttpa Tercapai). Jurnal Paramurobi, 1(1). https://scholar.google.co.id/sch

[9] Setiawati, F. (2006). Pendidikan Moral dan Nilai-nilai Agama Pada Anak Usia Dini : bukan suatu rutinitas.

[10] Syah, M. (2014). Psikologi Pendidikan dengan Pendekatan Baru (19th ed.). Remaja Rosakarya.

[11] Syamsudin, A. (2017). Evaluasi Ketercapaian Standar Isi Perkembangan 
Nilai-Nilai Agama Dan Moral Anak Usia Dini Pada Semester Gassal 2016/2017 $\mathrm{Kb} / \mathrm{Tk}$ Pedagogia. Evaluasi Ketercapaian Standar Isi Perkembangan Nilai-Nilai Agama Dan Moral Anak Usia Dini Pada Semester Gassal 2016/2017 Kb/Tk Pedagogia, 5(2), 765-777. https://doi.org/10.21831/jpa.v5i2.12374

[12] Thomas Lickona. (2016). Character Matters : How to help Our Children Develop Good Judgement,integrityand other essential Virtues (U. W. dan D. Budimansyah (ed.); 4th ed.). Bumi Aksara.

[13] Wina Sanjaya, M. (2015). Pembelajaran dalam Implementasi Kurikulum Berbasis Kompetensi (kencana (ed.); 6th ed.). Kharisma Putra Utama.

[14] WoonSuhc, A. A. W. J. P. D. V. F. J. S. (2017). Development of constructivist theory of mind from middle childhood to early adulthood and its relation to social cognition and behavior - ScienceDirect. Elsevier inc. https://doi.org/https://doi.org/10.1016/j.jec p.2016.10.002

[15]Zainuddin Syarif. (2014). Pendidikan Profetik Dalam Membentuk Bangsa Religius.

SekolahTinggiAgamaIslamMifahul Ulum Pamekasan, 9.

[16] Zulkifli N*. (2019). Dominant Factors Affecting the Development of Religious Values and Morals of Early Childhood in Childhood Early Education. Journal of Educational Sciences, 3(2), 184-194.

[17]Z A. M. K., \& , Samsudi, S. A. (2019). Implementation of Religious Character Planting of Low Grade Elementary School Students Learning in Islamic Elementary School in Purwokerto City. Educational Management, 8, 235. 